brood. In 1931 still greater catches should accrue. The course of events in the commercial fishery agreed very closely with the above prediction.

In the report now before us forecasts are made for an ensuing period as far forward as the middle of 1933. After the autumn of 1931, when most of the 1928 brood has been fished out, a sharp drop in the catches is predicted, owing to paucity of the 1929 and 1930 broods. Landings will continue below normal throughout 1932 and during at least the first half of 1933. The result of the 1931 spawning is not known at present, but a good brood is hoped for in order to relieve the depression which always follows when two successive years produce numerically unsatisfactory broods.

G. A. S.

\section{Mobilities of Atmospheric Large Ions}

A RECENT paper by R. K. Boylan entitled "The A Mobilities of Atmospheric Large Ions" * is of obvious importance in the subject of atmospheric electricity, which has engaged the attention of many meteorologists since Elster and Geitel's pioneer researches many years ago. Of the two classes of ion present in atmospheric air, the large ions of small mobility discovered by Langevin are normally the most numerous, and there is general agreement in fixing their mobility at $0.00033 \mathrm{~cm} . / \mathrm{sec} . / \mathrm{volt} / \mathrm{cm}$. These appear to be the principal nuclei of condensation for water vapour, and to be the result of small ions attaching themselves to uncharged particles of dust.

It is pointed out by Boylan that whereas McClelland and P. J. Nolan have found ions of smaller mobility in air treated in various artificial ways, such as bubbling through alcohol or passage over flames, it is generally believed that ions larger than the Langevin ions, that is, ions of smaller mobility, are absent from untreated air. Experiments conducted by Boylan on air in a well-ventilated room in Dublin gave strong reason for disbelieving this conclusion. Experiments were made on the usual lines, air being drawn at measured speeds between two lengths of concentric brass tubing, between which high tension electric fields of various known strengths were maintained, the current being measured by an electrometer. Since ions tend to group themselves around certain mobilities, these groups can be detected by looking for discontinuities in the curve obtained by plotting current against voltage; at such points all the ions of a given mobility are just collected on the inner electrode during the passage of the air through the tube. Boylan used both the McClelland and Zeleny methods of working with this apparatus, and tried many variations of air speed.

Curves derived by both methods agreed in showing clear evidence of the presence of several groups of large ions of mobilities higher and lower than that of the Langevin ions. So far from indicating 'saturation', that is, complete removal of ions, at a voltage corresponding with the mobility of the Langevin ion, the ionisation measured increased by amounts varying from 28 to 200 per cent when sufficient voltage to produce saturation was applied.

The difficulties of accurate measurement of the mobility of each group were very great; for the use of very high voltage or very slow speed, or some compromise between the two, is essential when dealing with such low mobilities, and each gives rise to its particular source of error or uncertainty. For this reason, Boylan does not claim to give a complete or accurate catalogue of the larger ions. Among the principal groups more mobile than the Langevin ions

- Proc. Royal Irish Academy, vol. 40, Section A, No. 4. may be mentioned those of mobility 0.0008 and 0.0006 , and among the less mobile groups those of mobility 0.0009 and 0.00006 . There was striking general agreement with many of the artificially produced groups observed by J. J. Nolan and by McClelland and P. J. Nolan. It is considered that very few of these ions would be found in the air of country districts.

E. V.N.

\section{University and Educational Intelligence}

Applications for Ramsay Memorial fellowships for chemical research, one of which will be limited to candidates educated in Glasgow, will be considered by the trustees at the end of June. Particulars of the fellowships can be obtained from the Secretary, Ramsay Memorial Fellowship Trust, University College, Gower Street, W.C.1. The application forms must be received by, at latest, May 31 .

THE Carnegie Trust for the Universities of Scotland has recently had under consideration the question whether, in view of the public assistance now available to the Scottish university student, the payment of class fees from funds dedicated under the Trust deed to this object should be continued. In its thirtieth annual report, the Trust's executive committee declares that the system whereby education authorities assist necessitous and deserving students has not yet reached in practice such a stage of development and uniformity as would warrant the immediate withdrawal from those eligible of the payment in part of class fees by the Trust, and that the special circumstances of the times are such as to render any such new departure inexpedient for the present. The amount spent by the Trust in this way in 1930-31 was $£ 56,366$. During the past four years, inquiry into the financial circumstances of each applicant's household has been made before admission to the benefits of the Trust, and it has been determined that in the case of all entrants to the university under twenty-one years of age the minimum standard of requirement for admission to these benefits shall be the obtaining of higher grade passes in three subjects in the Leaving Certificate Examination or in recog. nised equivalents. During the year, former beneficiaries have repaid a sum of $£ 1891$ voluntarily. The 'Trustees' scheme for the endowment of research is reported to be functioning very successfully. The awards, however, are limited to $£ 16,000$ a year, which is only half of the aggregate of the grants applied for.

"RADIo and Education" is the title of a short historical survey issued by the Office of Education, Washington, of the educational uses of wireless transmission in America. The work of amateurs is one phase of education by radio which the United States Army and Navy have in the past done much to foster. At the present time, there is a vast amount of direct instruction by broadcast lectures, one of the most important examples of which is the National Broadcasting Company's music appreciation hour directed by Walter Damrosch in connexion with the concerts of the New York Symphony Orchestra and listened to by some millions of pupils at every lecture. The 'American School of the Air' gives a half-hour period of instruction daily in historical drama, Nature study, vocational guidance, and a wide range of other topics which fit into the curricula of the public schools. Of the enterprises of State departments in this field, the Ohio School of the Air is the most extensive and thorough. Its programmes, comprising geography, rhythmic exercise, French, and other high-school subjects, are broadcast one hour each day and are

No. 3259, VoL. 129] 
listened to in twenty-nine States. There is a clash of interests between commercial and public institutional broadcasting, the demand for radio channels for commercial use having been so great that the right of the State to use this medium even for police purposes has been challenged. Practically all the commercial broad. casting stations devote much (in the aggregate about a tenth) of their time to 'educational "programmes. There are indications, however, that the advertising programmes are gradually displacing the educational, except at educational stations.

\section{Calendar of Geographical Exploration}

\section{April I9, I827.-The Niger and Timbuktu}

M. Caillié, a French government official of Sierra Leone, left Kakundy, on the Nunez river, midway between Sierra Leone. and the Gambia. With a small caravan of Mandingoes he crossed the region through which ran the upper tributaries of the Senegal and the Niger. He was the first European to enter the town of Jenné, on the Niger, though Park had seen it on his last journey. From Jenné he sailed down the Niger to Kabara, the port of Timbuktu, and reached that city on horseback. Caillié found the city to be a collection of mud huts, among which rose several rudely built mosques. To north-east and south of it spread vast deserts, and after a fortnight's stay, Caillié and his caravan began a march across the Sahara to Morocco. In one tract the travellers marched ten days without a drop of water; men and animals suffered severely, but ultimately Caillié won his way through Tafilet and the Atlas to Fez and Tangier. Timbuktu was first reached by a European in 1826, when Major Laing paid for his pioneer entry into the mysterious city with his life.

\section{April 20, I534.-Cartier and the St. Lawrence}

Jaques Cartier sailed from St. Malo, in charge of an expedition to look for a north-west passage to the Orient. He reached Newfoundland on May 10 , but was delayed by ice. Then began his series of explorations of the coasts of Newfoundland, Labrador, and the islands and straits off the coasts of Canada. In 1536 , on a second voyage, he sailed up the St. Lawrence estuary and reached the site of the present Montreal, of the scenery around which and of the Lachine Rapids he left a vivid description. Cartier's work in charting these coasts and discovering the region of the St. Lawrence, which was later settled by the French, was of outstanding importance.

\section{April 22, I500.-The Coast of Brazil}

Pedro Alvares Cabral sighted the coast of Brazil. $\mathrm{He}$ had been sent out by the Portuguese Government to follow up da Gama's discovery of an 'all sea' route to India, and da Gama had himself drawn up the sailing directions. In order to avoid the calms off the Gulf of Guinea, Cabral bore so far to the west that the coast of South America was discovered. Early in the same year the Spanish navigator, Vicente Yanez Pinson, had touched the coast of Brazil, but Cabral did not know of this.

\section{April 22, I 898.-Cambridge Expedition to the Torres Straits}

Dr. A. C. Haddon arrived at Thursday Island in charge of an expedition closely associated with the University of Cambridge. The expedition was of a unique character, for it was the first occasion on which investigations into the psychology of primitive peoples were carried out on a thoroughly scientific basis. Dr. Haddon gathered round him for this pioneer effort a brilliant group whose names are now world-famous in psychology, including the late Dr. W. H. R. Rivers, Dr. C. S. Myers, Prof. W. McDougall, and Prof. C. G. Seligman. The scientific data gathered have been published in several volumes, which have become standard sources of inspiration for all subsequent field workers in primitive psychology and in the social and physical anthropology of native peoples. The members of the expedition visited many islands in the Torres Straits, and also studied tribes in the Central and Mekeo districts of British New Guinea and in the Baram district of Sarawak. In 1888-89, Dr. Haddon paid a visit to the Torres Straits, and became deeply interested in the life of the natives; the confidence which he then inspired in them paved the way for the friendly relations essential for the success of scientific work among these 'head-hunting' tribes.

\section{April 22, 1908.-Stefansson in the Arctic}

Vilhjamur Stefansson set out on an expedition, during which he discovered several Eskimo tribes and obtained much information about their way of life. Stefansson began his career of exploration by archæological research in Iceland in 1904. In 1905 he turhed to arctic research, and by 1928 had spent ten winters and thirteen summers in scientific work north of the Polar Circle, always living like the Eskimo and therefore travelling light. The Canadian arctic expedition under Stefansson in 1913-18 is estimated " to have withdrawn nearly 100,000 square miles from the areas of unknown seas and lands". On this expedition the ship Karluk, carrying part of the group, was crushed in the ice and sank. Its crew reached Wrangel Island, where a relief ship rescued the survivors-Capt. Bartlett, commander of the Karluk, having bravely walked to Siberia to bring help.

April 23, I556.- The English on the Arctic Coast of Russia

The Searchthrift, commanded by Stephen Burrough, left Rateliffe on a voyage to search for the north-east, passage. Sebastian Cabot, then a very old man, came on board to wish them God-speed. Burrough met many Russian and Finnish lodjas (sailing boats with boards bound fast together by willows, not riveted): These fishing boats gave him much help, and were able to sail more easily and rapidly than the Searchthrift. Burrough, after reaching Vaygatz, returned to Kholmogory and wintered there, intending to proceed to the mouth of the Ob River next season. Instead of doing this, he turned westwards to search for Willoughby and the two vessels lost with him in the 1553 expedition. His voyage set up a new record of arctic penetration and made it clear how great were the difficulties of voyages in these very high latitudes. He brought back interesting accounts of the life and eustoms of the Samoyedes.

\section{Societies and Academies LONDON}

Geological Society, Feb. 24.-G. C. A. Jackson : The geology of the N'Changa district, Northern Rhodesia. The area, which forms part of the original Rhodesian Congo Border Concession, covers approximately 800 square miles, and lies immediately to the south of the Belgian Congo border. It is a wooded peneplain, underlain by four principal series of ancient metamorphosed and unfossiliferous sediments: namely, basement schists, Muva series, 